\title{
Efficiency and productivity of Brazilian banks: A new approach based on two-stage network DEA
}

\author{
Victor Eduardo de Mello Valerio ${ }^{\dagger}$ \\ Edson de Oliveira Pamplona \\ Marcelo Nunes Fonseca \\ Paulo Rotela Junior* \\ Luiz Célio Souza Rocha* \\ Rogério Santana Peruchi*
}

\begin{abstract}
This article creates a conceptual model, called a network system, to represent the Brazilian banking production system, based on its internal operational processes. The first, called the intermediation process, measures a bank's efficiency in extending loans from its available resources. The second, called the revenue process, measures a bank's efficiency in earning profit, mainly from loans granted. We adopt a two-stage DEA model. In the first stage, a relational network DEA model measures both the network system efficiency scores and internal processes. This technique, associated with the Malmquist Index, assesses performance changes over time. In the second stage, these efficiency scores are considered dependent variables, such that Tobit models can determine how the Brazilian credit market's characteristics can explain the network system and internal processes' efficiency. Results show not only a growing trend toward greater efficiency in the revenue process, but also an increase in productivity accompanied by a decline in the intermediation process technology. Given the high banking spreads in Brazil, these results indicate deterioration in the quality of the credit portfolio and the prospect of future insolvency. We discuss implications of this scenario for domestic banks and collateral policy.
\end{abstract}

Keywords: Two-stage DEA; Relational model; Malmquist index; Tobit; Brazilian banks. JEL Code: G2, G21.

Submitted on August 18, 2020. Revised on November 25, 2020. Accepted on September 15, 2021. Published online in December 2021. Editor in charge: Benjamin Miranda Tabak.

${ }^{\dagger}$ Institute of Production Engineering and Management - Federal University of Itajubá, Brazil:

victor.dmvegmail.com.

${ }^{\ddagger}$ Institute of Production Engineering and Management - Federal University of Itajubá, Brazil: pamplona@unifei.edu.br.

* Department of Production Engineering - Federal University of Goias, Brazil:

marcelonunes21@yahoo.com.br.

** Department of Production Engineering - Federal University of Paraiba, Brazil: paulo.rotela@gmail.com.

**** Federal Institute of Education, Science and Technology - North of Minas Gerais, Brazil: luizrochamgehotmail.com.

***** Department of Production Engineering - Federal University of Paraiba, Brazil:

rogerioperuchi@gmail.com. 


\section{Introduction}

This paper studies the performance of the Brazilian banking industry, applying the data envelopment analysis (DEA) model to general multi-stage systems (GMSS) (Kao, 2014), with panel data from the largest commercial banks. Unlike other DEA models, GMSS permits simultaneous computation of the efficiency of a production system and its corresponding internal processes without prior identification of the weights of aggregated products and inputs, but rather by the conventional definition of a ratio between aggregated output and input. Furthermore, GMSS permits relaxation of the assumption that internal processes do not consume exogenous inputs or do not produce exogenous outputs. These properties are particularly useful in studying a complex production system, comprised of a network of internal processes, as financial institutions are classified.

The credit market is strategic for the economic growth of emerging countries, insofar as financial intermediation activity boosts the flow of scarce resources to the productive sector (Levine et al., 2000; McCaig and Stengos, 2005; Boháček, 2007). This importance is attenuated in emerging countries, which generally do not have a developed capital market, giving the banks a worrying responsibility for increased liquidity (Tecles and Tabak, 2010). In contrast, the impact of intermediation activities on economic growth depends on the degree of financial sector development (Eggoh and Villieu, 2014). Because of this, research on the performance of the banking sector is essential (Berger and Humphrey, 1997; Paradi and Zhu, 2013; Liu et al., 2013b; Shyu et al., 2015).

Although a considerable amount of research applies DEA models to analyze the performance of the banking industry (Liu et al., 2013b; Guo et al., 2017; da Silva Fernandes et al., 2018; Li et al., 2018), few have focused on Brazil (Wanke and Barros, 2014). Brazil has the largest and most complex financial system in Latin America, and its banking industry has experienced an accelerated process of deep restructuring since the first half of the 1990s (Tecles and Tabak, 2010).

This restructuring originated with changes in the Brazilian regulatory framework. The purpose was to adjust the credit market to the new macroeconomic context of inflation stabilization, combined with a fiscal adjustment, and additionally to overcome the critical situation of the financial sector. The sector was characterized by highly leveraged institutions, and credit portfolios lacking strict supervision of risk (Barros and Wanke, 2014).

Therefore, regulatory reforms focused on encouraging privatization, accompanied by the sector opening to greater participation by foreign banks. 
What suffered were efforts to decrease the presence of public banks, hitherto focused on financing redistributive policy and fiscal policy. The whole process involved a large number of merger and acquisitions (M\&A) (Wanke et al., 2017). The plan was that the banking system's recovery would favor development and minimize the country's systemic financial instability.

Almost twenty years since the start of the restructuring process, evidence indicates that the Brazilian banking industry is close to its consolidation. However, the intense use of M\&A as a privatization and economic liberalization mechanism has resulted in an increase in the degree of banking concentration (Belaisch, 2003), characterized by an abrupt decrease in the number of institutions and the emergence of large banks and financial holding companies. Consequently, competition is decreasing (Yildirim and Philippatos, 2007).

Based on the foregoing, the motivation of this article can be described as follows. First, we evaluate at which efficiency levels the Brazilian credit market has been consolidating recently. Although similar studies exist, analysis of the Brazilian banking system, comprised of a financial intermediation process and a revenue process connected in a network, has not yet been explored. Second, using the Malmquist index, we carry out an intertemporal analysis of change in productivity and technology for each semester in a four-year period. This application extends the literature by combining the concepts of the Malmquist Index to network DEA-GMSS, measuring changes in the banking system and their internal processes in an integrated manner. Finally, we examine how the financial environment impacted the performance achieved by Brazilian banks through truncated Tobit models. This method is necessary to better understand the impact of the bank restructuring.

The remaining paper is organized as follows. Section 2 explains the conceptual framework of Brazil's banking industry. The purpose of Section 3 is to explain the proposed conceptual model used to analyze banking institutions. Section 4 intends to clarify the applied methodology. Section 5 details data analysis. Sections 6 and7 present empirical results and discusses their policy implications, respectively. Section 8 concludes.

\section{Overview of Brazilian banking industry}

Brazil's credit market was largely made up of public banks until the early 1990s. It represented 50\% of total bank assets and 55\% of total credits granted. Most loans were characterized as long-term. Based on this, some authors argue that public banks were important in funding investment, and thus to the country's economic growth (Ness, 2000; Beck et al., 2005).

However, in that time, banks were characterized by high administrative 
expenses, personnel expenses, and operational expenses. They depended chiefly on inflationary transfers to survive in the market. Brazil experienced double-digit inflation levels starting in the late 1950s, reaching a maximum level of about $2,708.17 \%$ per year in 1993 . Thus, the inflationary transfers to the Brazilian banking system were about $3.4 \%$ of gross domestic product (GDP) in the corresponding period (Franco, 2000; Nakane and Weintraub, 2005).

The critical situation of the banking sector was further intensified by macroeconomic changes introduced by the inflation stabilization plan, called the Real Plan. Inflation effectively converged at low levels. Thus, one of the main sources of public banks' income, and of the banking industry in general, was minimized. Inflationary transfers decreased to $1.8 \%$ of GDP in 1994, reaching $0.03 \%$ of GDP in 1995 . Specifically in relation to banks, inflationary transfers followed the same movement, decreasing from an average of 35\% of total revenues in 1993 to close to zero in 1995 (Franco, 2000; Nakane and Weintraub, 2005).

In addition, the Real Plan planned to maintain the basic interest rates at high levels. The purpose was to signal to the market the economic policy's commitment to stabilizing inflation. As a result, other real interest rates in the economy also increased, including Brazil's banking spreads Beck et al. (2005). Aiming to replace inflationary transfers, the banking industry greatly increased its financial intermediation activities. However, it did so without conducting a rigorous study of risk with borrowers, and without strict supervision by the Central Bank of Brazil (Ness, 2000; Nakane and Weintraub, 2005).

Accordingly, to contain the increase in financial intermediation and its corresponding impact on stimulating aggregate demand, the Central Bank increased the percentage of reserve requirements. In 1995, the rate of reserve requirement of new demand deposits increased from $40 \%$ to $100 \%$, while the rate of reserve requirements for time deposits was set at $20 \%$. As a result, many companies went bankrupt, either due to decreased demand, or from increased debt from the increased bank spreads. In addition, the banks' credit portfolio deteriorated significantly, with a simultaneous decrease in the financial sector's liquidity (Ness, 2000; Nakane and Weintraub, 2005).

Given the catastrophic situation in its banking industry, with high expenses and low revenues, rising defaults and decreased liquidity, Brazil's Central Bank implemented a broad and aggressive normative project to restructure the financial sector. Strictly speaking, this was divided in two phases (Tecles and Tabak, 2010; Staub et al., 2010). In the first phase, based on a 1987 law, the Temporary Special Administration Regime (RAET), the Cen- 
tral Bank assumed the responsibility to extra-judicially liquidate banks or to place them under special temporary management in the event of problematic liabilities. It simultaneously provided funds to insure customers' deposits (Barros and Wanke, 2014; Ness, 2000). In the second phase, two regulatory measures were drafted: the Program of Incentives for the Restructuring and Strengthening of the National Financial System (PROER) in 1995, and the Program of Incentives for the Restructuring of the State Public Financial System (PROES) in 1996.

After these acts, the public sector's share in the Brazilian credit market has been minimized. Some small public banks were liquidated. In addition, the tool of M\&A was used widely. Tax incentives were created and credit lines subsidized for both domestic and foreign banks to acquire public banks (Barros and Wanke, 2014; Ness, 2000). The Central Bank also passed Resolution 2,303 in 1996, allowing banks to increase revenues by charging fees for services.

The current situation of the Brazilian banking industry, since the regulatory changes implemented by the Central Bank, points to a process of bank consolidation, since no significant changes are observed in the number of banks and/or bank branches. Moreover, the sector composition related to bank ownership has shown some stabilization (Faria Júnior et al., 2006; Almeida and Jayme Jr., 2008).

In contrast, several studies show that, due to the mechanism of M\&A, consolidation of the banking system occurred at the cost of high levels of bank concentration, with negative impacts on the competitive structure of the credit market (Barros and Wanke, 2014; Yildirim and Philippatos, 2007). Furthermore, according to Olivero et al. (2011), current evidence suggests that the combination of banking concentration and an uncompetitive credit market weakens the financial intermediation activities in emerging countries, including Brazil. This hurts these countries' economic growth.

More recent studies assess the level of efficiency and solvency of the Brazilian credit market with respect to contextual variables (Wanke et al., 2015). They see levels of efficiency of financial institutions and their relationship with corporate governance practices and times of crisis (Freitas et al., 2018). They make international comparisons based on the experience of countries with similar cultures, such as Mozambique and Angola (Barros et al., 2018), and countries with similar socioeconomic conditions, such as the BRICS (Wanke et al., 2018).

In general, results of these recent analyses indicate that the efficiency levels of the Brazilian credit market are associated with public banks, the corporate practices adopted, the levels of gross savings, income inequality, and 
inflation in the country.

\section{Proposed model}

Financial intermediation refers to the process of banks organizing transfers of funds from surplus agents, savers, to deficit agents, investors and consumers. This is an ideal activity on which to evaluate bank performance, since these financial transactions can positively impact national economies. In addition, these activities are of proven importance to the banks themselves, representing up to two-thirds of total costs (Berger and Humphrey, 1997).

Seen from another angle, banks' solvency is closely related to the profitability of their operations. In this sense, granting problematic loans increases the probability of failure of these institutions (Seiford and Zhu, 1999; Luo, 2003; Avkiran, 2011). Along with showing this possible effect, analysis of the revenue process overlaps other aspects of financial performance, such as the cost perspective. This analysis provides substantial information on the competitive structure of credit markets, see Berger and Humphrey (1997).

Figure 1 illustrates the production system we propose to represent banks. In this system, two internal processes make up the network structure. In the first case, we selected variables to assess a bank's efficiency in its lending activities, i.e. the intermediation process. In the second case, the variables must provide evidence of the bank's efficiency in producing income, also primarily from intermediation activities it performs, i.e. the revenue process.

As Figure 1 shows, the evaluation designed for the intermediation process measures bank efficiency in performing activities of financial intermediation, represented by outputs credit operations $\left(Z_{1}\right)$ and securities investments $\left(Z_{2}\right)$; using its available resources, represented by the inputs labor $\left(X_{1}\right)$, capital $\left(X_{2}\right)$, and deposits $\left(X_{3}\right)$. In addition, we add a third output, the Basel index $\left(Y_{1}\right)$, because a bank is not considered efficient when it increases the volume of loans without ensuring minimally adequate equity conditions. This design takes into account the fundamentals of Berger and Humphrey (1997), Sturm and Williams (2010) and Faria Júnior et al. (2006).

More specifically, the outputs credit operations $\left(Z_{1}\right)$ and securities investments $\left(Z_{2}\right)$ represent the total loans granted and total investments in stocks and bonds held by a bank, respectively. The output Basel index $\left(Y_{1}\right)$ corresponds to the net equity requirements imposed by the Basel Agreement. On the other side, the labor input $\left(X_{1}\right)$ is the sum of personnel and other administrative expenses, capital $\left(X_{2}\right)$ is the sum of fixed components of assets, and deposits $\left(X_{3}\right)$ equal the total deposits available at the bank. 


\section{Figure 1}

Bank system composed by intermediation and revenue processes

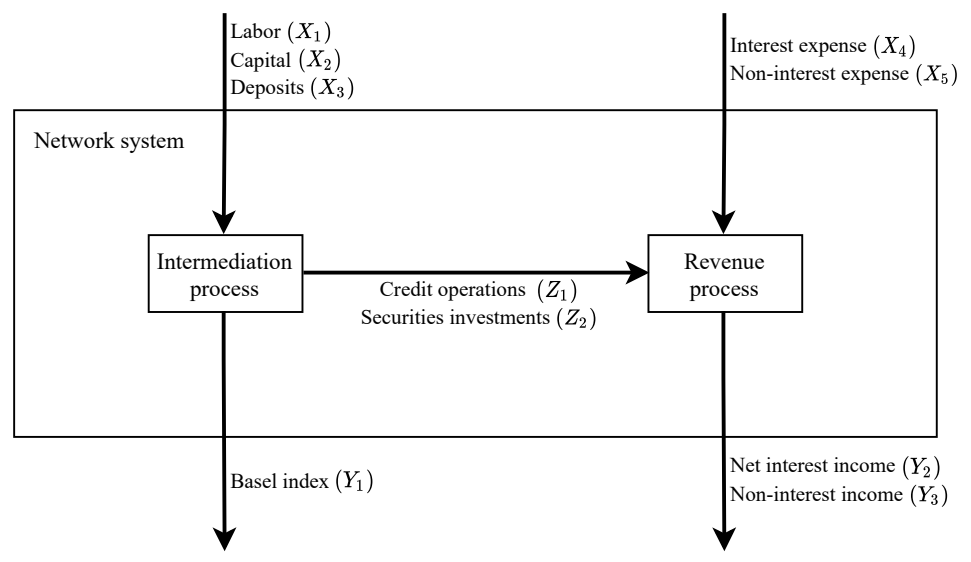

Continuing with Figure 1, we evaluate the revenue process with measures of a bank's efficiency in making profit, represented by outputs net interest income $\left(Y_{2}\right)$ and non-interest income $\left(Y_{3}\right)$ after incurring expenses represented by inputs interest expense $\left(X_{4}\right)$ and non-interest expense $\left(X_{5}\right)$. We consider the fundamental ideas of Berger and Humphrey (1997), Seiford and Zhu (1999), Luo (2003), Sturm and Williams (2010), Faria Júnior et al. (2006), and Avkiran (2011) in this design.

The outputs net interest income $\left(Y_{2}\right)$ and non-interest income $\left(Y_{3}\right)$ are the total income from financial intermediation and the sum of service incomes and other operating incomes, respectively. The inputs interest expense $\left(X_{4}\right)$ and non-interest expense $\left(X_{5}\right)$ correspond to the total expense of financial intermediation and the sum of taxes and other operating expenses, respectively.

In the proposed banking production system, we see that the revenue and intermediation processes are connected in a series network structure, from the endogenous variables credit operations $\left(Z_{1}\right)$ and securities investments $\left(Z_{2}\right)$. The idea is that efficiency results from both the volume of intermediation activity realized and the expenses incurred. The other variables are exogenous, forming a parallel network structure. This allows a full system scan. This complex network structure, wherein the production system variables are linked in series and in parallel simultaneously, supports the application of GMSS. 


\section{Methodological fundamentals}

\subsection{DEA-GMSS model background}

Many studies analyze the performance of the banking industry. Most of these studies use DEA models (Paradi and Zhu, 2013; Li et al., 2018). According to Liu et al. (2013a), bank efficiency analysis using DEA models corresponds to a search field trend, since much of this method's development has been tailored to the specific needs of this type of study.

The DEA model employs a non-parametric technique to assess the relative efficiency of decision making units (DMUs). The DMUs perform the same operations, and therefore use many similar inputs to generate outputs that are also similar (Banker et al., 2011; liang Yang et al., 2018). Based on concepts of productivity and efficiency introduced by Farrell (1957), the first DEA model was developed by Charnes et al. (1978).

Liu et al. (2013a) and Lampe and Hilgers (2015) explain that from that initial DEA model, a number of other, more sophisticated, DEA models have been developed. These newer models meet different objectives of relative efficiency analysis. Among the various types of models currently available, one relevant approach involves examining a DMU's performance from the perspective of network structures, i.e. network DEA models.

Fukuyama and Mirdehghan (2012) define network structure as a system that processes inputs into outputs. It consists of the internal production processes linked together, whereby the composition of these processes produces the final output of the DMU. Rho and An (2007), Ebrahimnejad et al. (2014), and liang Yang et al. (2018) argue that developing network DEA models is necessary, since traditional DEA models, called "black box" models, may measure efficiency inaccurately. Black box measures do not incorporate the performance of internal processes of DMUs. Thus, they may consider a DMU to be efficient, despite it having inefficient internal processes.

As Kao (2014), Liu et al. (2013a), Lampe and Hilgers (2015), and Mariz et al. (2018) explain, early work on network DEA models is credited to Färe (1991), Färe and Whittaker (1995), and Färe and Grosskopf (1996). However, it was only Kao and Hwang (2008) who began to compute system efficiencies and their respective internal processes simultaneously in the same model. Since then, a number of researchers have incorporated internal processes to compute DMU performance in various ways, as shown by $\mathrm{Yu}$ and Lin (2008), Avkiran (2009), Tone and Tsutsui (2009), Kao and Hwang (2008), Kao (2009a,b), and Chen et al. (2009).

According to Mariz et al. (2018), of the different methods to assess production systems' performance using network DEA, Kao (2014) proposes an 
improved model, called general multi-stage systems (GMSS). GMSS is based on the decomposition of multiple processes in multiple system stages. From that decomposition, the system is transformed into a network structure. Its efficiency is expressed as a function of the efficiency of each process simultaneously. The approach of decomposition of system efficiency has important properties: 1. no limitation on the type of network structure, allowing the whole complex system to be modeled; 2 . no need to pre-set the weights of the internal processes to compose system efficiency, reducing the risk of inaccuracy in estimating efficiency; 3. possibility of relaxing the constraints of non-use and/or no production, of exogenous variables in the system's internal processes.

According to Kao (2014), the system efficiency estimation $\left(\theta_{k}\right)$, of a DMU $k$, from a total of $n \in N$ DMUs, $j=1,2, \ldots, n \mid k \in N$, given $q$ internal processes, $p=1,2, \ldots, q$, is defined in the GMSS as

$$
\max \theta_{k}=\sum_{r=1}^{s} u_{r} Y_{r k}
$$

subject to

$$
\left\{\begin{array}{l}
\sum_{i=1}^{m} v_{i} X_{i k}=1 \\
\sum_{r=1}^{s} u_{r} Y_{r j}-\sum_{i=1}^{m} v_{i} X_{i j} \leq 0, \\
\sum_{r \in O^{(p)}} u_{r} Y_{r j}^{(p)}+\sum_{f \in M^{(p)}} w_{f} Z_{f j}^{(p)} \leq \sum_{i \in I^{(p)}} v_{i} X_{i j}^{(p)}+\sum_{f \in M^{(p-1)}} w_{f} Z_{f j}^{(p-1)}, \\
u_{r}, v_{i}, w_{f} \geq \varepsilon,
\end{array}\right.
$$

for all $j=1, \ldots, n ; p=2, \ldots, q-1 ; r=1, \ldots, s ; i=1, \ldots, m$; and $f=1, \ldots, g$.

Still in reference to the GMSS model proposed by Kao (2014), to denote the set $\left(u_{r}^{*}, v_{i}^{*}, w_{f}^{*}\right)$ as an optimal solution, and $s_{k}^{*}$ and $s_{k}^{(p)^{*}}$ as the slacks added to the constraints of the system and of the process $p$, respectively, the system efficiency $\left(\theta_{k}\right)$ and its decomposition to their internal processes $\left(\theta_{k}^{(p)}\right)$, are defined as

$$
\theta_{k}=\frac{\sum_{r=1}^{s} u_{r}^{*} Y_{r k}}{\sum_{i=1}^{m} v_{i}^{*} X_{i k}}=\sum_{r=1}^{s} u_{r}^{*} Y_{r k}=1-s_{k}^{*}
$$

and

$$
\theta_{k}^{(p)}=\frac{\sum_{r \in O^{(p)}} u_{r}^{*} Y_{r k}^{(p)}+\sum_{f \in M^{(p)}} w_{f}^{*} Z_{f k}^{(p)}}{\sum_{i \in I^{(p)}} v_{i}^{*} X_{i k}^{(p)}+\sum_{f \in M^{(p-1)}} w_{f}^{*} Z_{f k}^{(p-1)}}
$$


for $p=2, \ldots, q-1$.

In this way, the system's slack is defined as the sum of the slacks computed for each internal process $s_{k}^{*}=\sum_{p=1}^{q} s_{k}^{(p)^{*}}$. This is the main property of GMSS. A corollary is that the system will only be efficient if all internal processes are also efficient, thus eliminating the errors and efficiency estimation inaccuracies of the black box DEA models.

Using these definitions, this paper applies the DEA-GMSS model to estimate the efficiency of banks that operated in the Brazilian credit market in each semester during a four-year period. This application allows an estimation of a bank's production system efficiency score, and of its intermediation and revenue processes. It provides a fairly complete picture of bank performance in each time period.

\subsection{Decomposition of the Malmquist productivity index for GMSS}

The Malmquist productivity index (MPI), originally proposed by Malmquist (1953) and Caves et al. (1982), aims to measure the change in the total factor productivity incurred by a DMU in adjacent periods of time. The MPI can be estimated with DEA models. This index is used in different approaches to study the performance of the financial sector; see Berg et al. (1992), Berg et al. (1993), Portela and Thanassoulis (2010), and Wijesiri and Meoli (2015). Furthermore, due to its precision, the MPI is one of the most frequently used indexes to estimate performance variations (Pastor et al., 2011).

From the proposal of Färe et al. (1994), the change in the total productivity factor can be computed through its disaggregation into two mutually exclusive and exhaustive components: change in technical efficiency and change in technology. These components are defined as representations of a DMU's recovery and innovation, respectively. Therefore, under the DEA, MPI equals the change in technical efficiency weighted by the change in technology. The latter is interpreted as a change in the efficiency frontier, which is calculated from a Fischer index.

Färe et al. (1994) present the adjacent periods as $t, t^{\prime}=1,2 \mid t \neq t^{\prime} ; t, t^{\prime} \in T$. Also, $\left(\theta_{k}^{T} \mid \phi^{T}(\boldsymbol{x}, \boldsymbol{y})\right)$ is the efficiency achieved by the DMU $k$ considering their productivity in the period $T$ designed in efficiency frontier observed in the period $T$, given a set of $n \in N$ DMUs, $j=1,2, \ldots, n \mid k \in N$. Thus, the MPI is calculated as

$$
\operatorname{MPI}_{k}=\frac{\left(\theta_{k}^{2} \mid \phi^{2}(\boldsymbol{x}, \boldsymbol{y})\right)}{\left(\theta_{k}^{1} \mid \phi^{1}(\boldsymbol{x}, \boldsymbol{y})\right)}\left(\frac{\left(\theta_{k}^{2} \mid \phi^{1}(\boldsymbol{x}, \boldsymbol{y})\right)}{\left(\theta_{k}^{2} \mid \phi^{2}(\boldsymbol{x}, \boldsymbol{y})\right)} \frac{\left(\theta_{k}^{1} \mid \phi^{1}(\boldsymbol{x}, \boldsymbol{y})\right)}{\left(\theta_{k}^{1} \mid \phi^{2}(\boldsymbol{x}, \boldsymbol{y})\right)}\right)^{\frac{1}{2}}
$$

The first term of the MPI corresponds to the estimated change in technical 
efficiency, while the second term refers to the estimated change in technology, considering the fixed reference base in the period. In addition, each efficiency $\left(\theta_{k}^{\bar{T}} \mid \phi^{\bar{T}}(\boldsymbol{x}, \boldsymbol{y})\right)$ achieved by a DMU $k$, from a combination of its productivity in period $\bar{T}, \forall \bar{T} \in T$, projected on the frontier of period $\bar{T}^{\prime}, \forall \bar{T}^{\prime} \in T$ is obtained recursively through the DEA model, as follows:

$$
\max \left(\theta_{k}^{\bar{T}} \mid \phi^{\bar{T}^{\prime}}(\boldsymbol{x}, \boldsymbol{y})\right)=\sum_{r=1}^{s} u_{r} Y_{r k}^{\bar{T}}
$$

subject to

$$
\left\{\begin{array}{l}
\sum_{i=1}^{m} v_{i} Y_{i k}^{\bar{T}} \\
\sum_{r=1}^{s} u_{r} Y_{r k}^{\bar{T}} \leq \sum_{i=1}^{m} v_{i} Y_{i k}^{\bar{T}} \\
\sum_{r=1}^{s} u_{r} Y_{r j}^{\bar{T}^{\prime}} \leq \sum_{i=1}^{m} v_{i} Y_{i j}^{\bar{T}^{\prime}} \\
u_{r}, v_{i} \geq \varepsilon
\end{array}\right.
$$

for all $r=1, \ldots, s ; i=1, \ldots, m$; and $j \neq k$.

However, as already explained, the using black box DEA models can generate efficiency inference errors, since efficiency can be imputed to the system of a DMU operating with inefficient internal processes. Thus the subsequent measurement of change in productivity and change in technology also incur error, to the extent that the inaccurate efficiency estimation of the DEA model is propagated in the calculation of the MPI (Kao, 2017).

Some recent investigators seek to overcome this limitation; see Kao and Liu (2014) and Kao (2017). In this study, we propose an association between the DEA-GMSS model of Kao (2014) and MPI (Färe et al., 1994). On the one hand, adopting the DEA-GMSS model is justified to eliminate inaccuracy in estimating efficiency, and to simultaneously incorporate information about internal processes. DEA-GMSS can be applied to any complex network structure, broadening the scope of our proposal to other research. Adopting MPI is also justified, because it is possible to decompose the performance change in its components of productivity and technology. This information is crucial, to provide a complete view of the banking sector's degree of development, a factor that impacts countries' economic growth.

Based on the foregoing, our proposal is to calculate the MPI for the system, and in an integrated manner, calculate the MPI for its internal processes in a relational network DEA model. Thus, defining $\mathrm{MPI}_{k}$ as the Malmquist 
index calculated for the system, and $\operatorname{MPI}_{k}^{(p)}$ as the Malmquist index calculated for each process $p=1,2, \ldots, q$, we have

$$
\operatorname{MPI}_{k}=\frac{\left(\theta_{k}^{2} \mid \phi^{2}(\boldsymbol{x}, \boldsymbol{y})\right)}{\left(\theta_{k}^{1} \mid \phi^{1}(\boldsymbol{x}, \boldsymbol{y})\right)}\left(\frac{\left(\theta_{k}^{2} \mid \phi^{1}(\boldsymbol{x}, \boldsymbol{y})\right)}{\left(\theta_{k}^{2} \mid \phi^{2}(\boldsymbol{x}, \boldsymbol{y})\right)} \frac{\left(\theta_{k}^{1} \mid \phi^{1}(\boldsymbol{x}, \boldsymbol{y})\right)}{\left(\theta_{k}^{1} \mid \phi^{2}(\boldsymbol{x}, \boldsymbol{y})\right)}\right)^{\frac{1}{2}}
$$

and

$$
\operatorname{MPI}_{k}^{(p)}=\frac{\left(\theta_{k}^{2,(p)} \mid \phi^{2,(p)}(\boldsymbol{x}, \boldsymbol{y})\right)}{\left(\theta_{k}^{1,(p)} \mid \phi^{1,(p)}(\boldsymbol{x}, \boldsymbol{y})\right)}\left(\frac{\left(\theta_{k}^{2,(p)} \mid \phi^{1,(p)}(\boldsymbol{x}, \boldsymbol{y})\right)}{\left(\theta_{k}^{2,(p)} \mid \phi^{2,(p)}(\boldsymbol{x}, \boldsymbol{y})\right)} \frac{\left(\theta_{k}^{1,(p)} \mid \phi^{1,(p)}(\boldsymbol{x}, \boldsymbol{y})\right)}{\left(\theta_{k}^{1,(p)} \mid \phi^{2,(p)}(\boldsymbol{x}, \boldsymbol{y})\right)}\right)^{\frac{1}{2}} .
$$

The system efficiencies $\left(\theta_{k}^{\bar{T}} \mid \phi_{k}^{\bar{T}^{\prime}}(\boldsymbol{x}, \boldsymbol{y})\right)$, arising from productivity combinations projected in the frontier, when considering adjacent periods, are initially calculated by the DEA-GMSS model:

$$
\max \left(\theta_{k}^{\bar{T}} \mid \phi_{k}^{\bar{T}^{\prime}}(\boldsymbol{x}, \boldsymbol{y})\right)=\sum_{r=1}^{s} u_{r} Y_{r k}^{\bar{T}}
$$

subject to

$$
\left\{\begin{array}{l}
\sum_{i=1}^{m} v_{i} X_{i k}^{\bar{T}}=1 \\
\sum_{r=1}^{s} u_{r} Y_{r k}^{\bar{T}} \leq \sum_{i=1}^{m} v_{i} X_{i k}^{\bar{T}} \\
\sum_{r=1}^{s} u_{r} Y_{r j}^{\bar{T}^{\prime}} \leq \sum_{i=1}^{m} v_{i} X_{i j}^{\bar{T}^{\prime}} \\
\sum_{r \in O^{(p)}} u_{r} Y_{r k}^{\bar{T},(p)}+\sum_{f \in M^{(p)}} w_{f} Z_{f k}^{\bar{T},(p)} \leq \sum_{i \in I^{(p)}} v_{i} X_{i k}^{\bar{T},(p)}+\sum_{f \in M^{(p-1)}} w_{f} Z_{f k}^{\bar{T},(p-1)} \\
u_{r}, v_{i}, w_{f} \geq \varepsilon,
\end{array}\right.
$$

for all $p=2, \ldots, q-1 ; r=1, \ldots, s ; i=1, \ldots, m ; f=1, \ldots, g$; and $j \neq k$.

For each system efficiency, we decompose efficiencies for $q$ internal processes, where $p=1,2, \ldots, q$. If the set $\left(\tilde{u}_{r}^{*}, \tilde{v}_{i}^{*}, \widetilde{w}_{f}^{*}\right)$ is the optimal solution for a given combination of productivity and efficiency frontier, and $\tilde{s}_{k}^{*}$ and $\tilde{s}_{k}^{(p)^{*}}$ are the slacks added to the system and process $p$ constraints, respectively, the system efficiency $\left(\theta_{k}^{\bar{T}} \mid \phi^{\bar{T}^{\prime}}(\boldsymbol{x}, \boldsymbol{y})\right)$ and its decomposition to their internal processes $\left(\theta_{k}^{\bar{T},(p)} \mid \phi^{\bar{T}^{\prime},(p)}(\boldsymbol{x}, \boldsymbol{y})\right)$ are defined as

$$
\left(\theta_{k}^{\bar{T}} \mid \phi^{\bar{T}^{\prime}}(\boldsymbol{x}, \boldsymbol{y})\right)=\frac{\sum_{r=1}^{s} \tilde{u}_{r}^{*} Y_{r k}^{\bar{T}}}{\sum_{i=1}^{m} \tilde{v}_{i}^{*} X_{i k}^{\bar{T}}}=\sum_{r=1}^{s} \tilde{u}_{r}^{*} Y_{r k}^{\bar{T}}=1-\tilde{s}_{k}^{*}
$$


and

$$
\left(\theta_{k}^{\bar{T},(p)} \mid \phi^{\bar{T}^{\prime},(p)}(\boldsymbol{x}, \boldsymbol{y})\right)=\frac{\sum_{r \in O^{(p)}} \tilde{u}_{r}^{*} Y_{r k}^{\bar{T},(p)}+\sum_{f \in M^{(p)}} \tilde{w}_{f}^{*} Z_{f k}^{\bar{T},(p)}}{\sum_{i \in I^{(p)}} \tilde{v}_{i}^{*} X_{i k}^{\bar{T},(p)}+\sum_{f \in M^{(p-1)}} \tilde{w}_{f}^{*} Z_{f k}^{\bar{T},(p-1)}}
$$

for $p=2, \ldots, q-1$.

Thus, it becomes possible to measure the change in productivity and technology, both for the system network and for each of the internal processes.

We use the proposed integration of the DEA-GMSS model and MPI to measure the change in productivity and technology experienced by each DMU between semesters for four years. In addition, we measure the respective changes between the extremes of the period. This application is important for allowing the changes to be estimated for the production system of the bank, and for intermediation and revenue processes. Furthermore, the analysis of each semester and between the extreme periods has the potential to provide important information about a possible influence of the activity cycle on banks' performance (Berg et al., 1993).

\subsection{Two-stage analysis}

The second-stage analysis corresponds to an evaluation of the effect of contextual or environmental variables on production efficiency through a twostage process. In the first stage, the DEA model provides the DMU's efficiency scores. In the second phase, these scores are correlated with some contextual variables relevant to the study (Liu et al., 2013a).

The second-stage analyses are essential to broaden our knowledge of the transformation process. They thus have the potential to improve the quality of management strategies defined by market operators and/or to guide policy makers towards best practices (Johnson and Kuosmanen, 2012). This perspective takes on special importance for studies aimed at analyzing credit market performance, as contextual variables significantly influence the efficiencies achieved by banks (Berger and Humphrey, 1997).

A wide range of statistical procedures exist for second-stage analysis; see Simar and Wilson (2007) and Banker and Natarajan (2008). Among these, the Tobit regression truncated at 1 has been widely used (Turner et al., 2004; Hoff, 2007). Simar and Wilson (2007) describe limitations of the truncated Tobit regression due to the possibility of inconsistent estimators. The second-stage variables may be correlated with the efficiency scores measured by the DEA model in the first stage. However, there is no guarantee that other estimates, such as the bootstrap, are more reliable, since they require a series of initial assumptions about the samples of variables (Çelen, 2013). 
Moreover, Banker and Natarajan (2008) show that the truncated Tobit model presents satisfactory results in predicting the levels of efficiency. In addition, they sidestep sampling problems by selecting context variables to reduce their correlation with the efficiency scores. Moreover, as we see in the next section, the authors use a significant representation of the banking industry in Brazil.

The relative efficiency scores of a DMU's sample, calculated in the first stage via DEA programming, clearly correspond to a sample with strictures, since the respective scores can take any real value between 0 and 1 (Johnson and Kuosmanen, 2012). Thus, to set this efficiency score of DMU $k$, denoted by $\theta_{k h}$, in terms of $h$ contextual variables $\boldsymbol{\delta}_{k h}$, with $l=1, \ldots, h$, the latent variable $\hat{\theta}_{k h}$, which is dependent on the same contextual variables, is defined by

$$
\hat{\theta}_{k h}=\boldsymbol{\delta}_{k h}^{\prime} \boldsymbol{\beta}+\varepsilon_{k h}
$$

where $\boldsymbol{\delta}_{k h}$ is a vector $(h \times 1)$ of contextual variables; $\boldsymbol{\beta}$ is a vector $(h \times 1)$ of parameters to be estimated; and $\varepsilon_{k h} \approx N\left(0 ; \sigma^{2}\right)$.

Using the aforementioned latent variable, we may obtain the observed efficiency score from the stricture, below 0 and above 1 , such that

$$
\theta_{k h}= \begin{cases}0, & \text { if } \hat{\theta}_{k h} \leq 0 \\ \hat{\theta}_{k h,} & \text { if } 0<\hat{\theta}_{k h}<1 \\ 1, & \text { if } \hat{\theta}_{k h} \geq 1\end{cases}
$$

Considering this structuring of the truncated Tobit model, the maximum likelihood method makes it possible to estimate the values of $\boldsymbol{\beta}$ parameter vector. The non-application of this formulation structure for Tobit regression by maximum likelihood method ultimately can cause problems of estimation inconsistency (Greene, 2018).

Taking this systematization into account, we perform a second-stage analysis from the integration of efficiency scores measured by DEA-GMSS, in the first stage, and the Tobit model truncated to 1, in the second stage. We define the contextual variables by the domains ownership, size, and type of institution. With this application, we aim to capture how the current structure of the Brazilian credit market, a consequence of the regulatory restructuring implemented by the Central Bank, impacts the performance of banks.

\section{Data analysis}

We collected data from sectorial technical reports organized, audited, and provided quarterly by the Central Bank of Brazil. More specifically, we used 
the report named Selected Information On Supervised Institutions. ${ }^{1}$ This report consists of the financial statements of financial holding companies and of banking institutions that are not part of a financial holding company, but that are in normal operation. This proves to be the best database available for analysis of the Brazilian banking sector.

We selected 30 banks operating in the Brazilian credit market. The criterion for selecting banks was the highest value of total assets, considering values from the year 2015. This sample accounts for $92.60 \%$ of total bank assets and $92.03 \%$ of total bank deposits. We consider the year 2015 to be representative of the recent conditions of the banking industry in Brazil.

We avoided analyzing a larger number of banks to decrease the sample dispersion. Given the level of concentration of the Brazilian banking sector, increasing the number of banks would bring only a small marginal contribution in total bank assets and total bank deposits. Our procedure aims to minimize the effects of scale heteroskedasticity in measured technical efficiency levels (Berger and Humphrey, 1997; Yuengert, 1993).

Regarding the defining criterion of the time interval, we sought to distance the performance analysis from periods near the subprime crisis of 2008. We decided this because of evidence that, in the short term, some financial instability is expected due to the banks adjusting to a significant crisis. This instability of adaptation can be confused with technical inefficiency in banking performance analysis (Siriopoulos and Tziogkidis, 2010).

Table 1 presents descriptive statistics for each variable of our proposed banking system model. With the exception of the Basel Agreement, because it is a financial ratio, the variables are expressed in terms of $1,000,000.00$ Brazilian Real Rates (BRL).

Regarding MPI, in order to project values on the efficiency frontier built in another period, we deflated the monetary values of the DMU variables under analysis to the respective period of the efficiency frontier. To do this, we relied on the evolution of the general price index (IGP-DI). We implemented this mechanism to minimize the effects of relative prices changes in bank productivity and technology analysis.

Regarding the structure of the second-stage analysis, the three areas: ownership, size, and type of institution, are qualitative. Ownership has three categories: public, domestic, and foreign. For each category, we created a dummy variable by assigning the value 1 if true and 0 otherwise. Size has two categories: large and small. We created another dummy variable with the value 1 for large and 0 for small. The type of institution has two categories: financial holding companies and banking institutions that are not part of a financial

${ }^{1}$ This report is available at https://www3.bcb.gov.br/informes/relatorios 


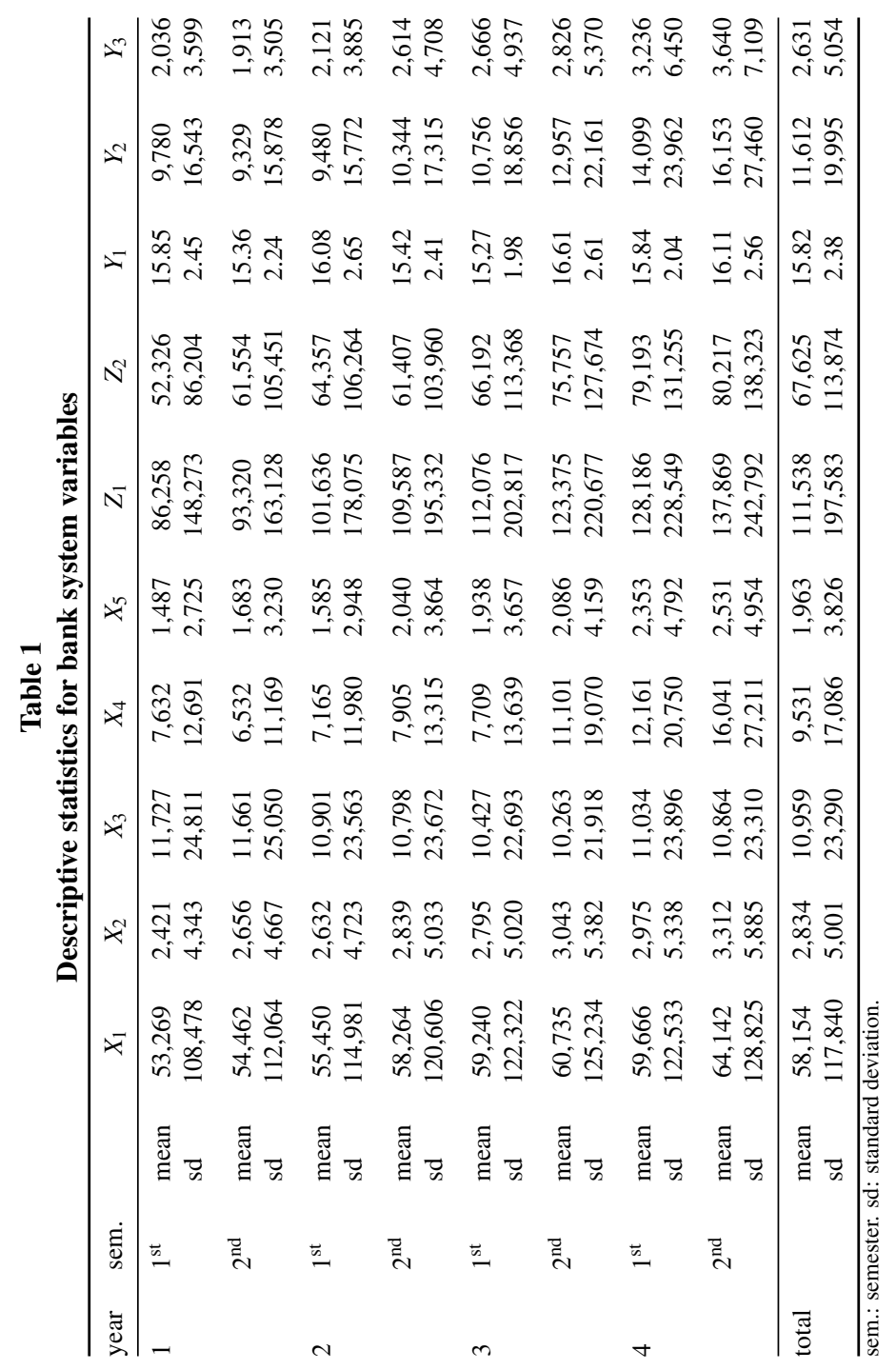


Table 2

Descriptive statistics for efficiency estimates

\begin{tabular}{|c|c|c|c|c|c|c|c|}
\hline \multirow[b]{2}{*}{ year } & \multirow[b]{2}{*}{ sem. } & \multicolumn{2}{|c|}{ network system } & \multicolumn{2}{|c|}{ intermadiation process } & \multicolumn{2}{|c|}{ revenue process } \\
\hline & & mean & $\mathrm{sd}$ & mean & $\mathrm{sd}$ & mean & $\mathrm{sd}$ \\
\hline \multirow[t]{2}{*}{1} & $1^{\text {st }}$ & 0.769 & 0.208 & 0.617 & 0.322 & 0.711 & 0.203 \\
\hline & $2^{\text {nd }}$ & 0.747 & 0.214 & 0.632 & 0.306 & 0.715 & 0.200 \\
\hline \multirow[t]{2}{*}{2} & $1^{\mathrm{st}}$ & 0.802 & 0.207 & 0.659 & 0.316 & 0.751 & 0.199 \\
\hline & $2^{\text {nd }}$ & 0.786 & 0.145 & 0.587 & 0.299 & 0.784 & 0.157 \\
\hline \multirow[t]{2}{*}{3} & $1^{\mathrm{st}}$ & 0.819 & 0.168 & 0.615 & 0.309 & 0.804 & 0.170 \\
\hline & $2^{\text {nd }}$ & 0.815 & 0.163 & 0.609 & 0.287 & 0.786 & 0.166 \\
\hline \multirow[t]{2}{*}{4} & $1^{\mathrm{st}}$ & 0.829 & 0.162 & 0.642 & 0.295 & 0.805 & 0.167 \\
\hline & $2^{\text {nd }}$ & 0.798 & 0.171 & 0.637 & 0.297 & 0.777 & 0.161 \\
\hline total & & 0.796 & 0.180 & 0.625 & 0.304 & 0.767 & 0.1780 \\
\hline
\end{tabular}

holding company. Therefore, we created a final dummy variable, assigning the value 1 for holding and 0 otherwise. In order to highlight the marginal contributions of each variable included in the regression, and simultaneously eliminate the situation of perfect multicollinearity, we made estimates without intercept (Greene, 2018).

Over the four-year period, the analysis domains did not change for any bank. Moreover, the ownership information and type of institution are explicitly provided in the Central Bank of Brazil's report. We categorized institution size based on the number of bank branches. We denoted as large those banks with a number of branches higher than three digits, in line with the specificities of the Brazilian credit market, as used by (Barros and Wanke, 2014).

\section{Results and discussion}

\subsection{DEA network system results}

Table 2 shows the descriptive statistics of efficiency scores achieved by the Brazilian banking system, and by their internal processes over each period studied. At the end, descriptive statistics calculated for the total data panel are added.

Table 2 shows that the Brazilian credit market operated with high levels of inefficiency throughout all periods studied. The banking system in total panel obtained a mean score of 0.7958 in efficiency. Both internal processes considered in the model propitiated these bad performances, as can be attested by the average efficiency scores of 0.6248 and 0.7667 in intermediation and 
Table 3

\begin{tabular}{lll}
\multicolumn{3}{c}{$\begin{array}{c}\text { Mann-Whitney } \chi^{2} \text { tests for } \\
\text { intermediation and revenue processes }\end{array}$} \\
\hline year & sem. & $p$-value \\
\hline 1 & $1^{\text {st }}$ & 0.157 \\
& $2^{\text {nd }}$ & 0.230 \\
2 & $1^{\text {st }}$ & 0.415 \\
& $2^{\text {nd }}$ & $0.008^{* * *}$ \\
3 & $1^{\text {st }}$ & $0.021^{* *}$ \\
& $2^{\text {nd }}$ & $0.013^{* *}$ \\
4 & $1^{\text {st }}$ & $0.040^{* *}$ \\
& $2^{\text {nd }}$ & $0.092^{*}$
\end{tabular}

sem.: semester. *;**;***: Statistical significance at $10 \%$, $5 \%$, and $1 \%$, respectively. $p$-value adjusted for ties.

revenue processes, respectively. When comparing the average results of efficiency obtained in the system of internal processes, it appears that the banking industry has tended to be more efficient in obtaining revenue from loans at the expense of proper supply credit from available resources.

Table 3 shows the results of the Mann-Whitney test, designed to analyze the null hypothesis that there is no significant difference in performance between the internal processes in each time period. It is understood that the trend of better revenue process performance gradually became significant over the semesters.

\subsection{Malmquist productivity index results}

Table 4 shows the Malmquist Productivity Index (MPI) results. The results show that the average of financial technologies in Brazil's credit market deteriorated in almost all short-term intervals, thus causing an average technological decrease of $0.66 \%$ in the banking system over the entire reporting period. The observed decrease originated in great extent from the deterioration of revenue process, since the average of technologies related to revenue support worsened by $10.99 \%$ over an average increase of $3.95 \%$ in financial intermediation technologies, also to be considered the total period.

In the opposite direction, the average productivity of the Brazil credit market increased in most short-term intervals, resulting in an average increase of $5.29 \%$ in the productivity factor, analyzed over the entire period. This evolution of total bank system productivity was driven by both internal processes, with average growth over the period of $50.96 \%$ and $3.34 \%$ for intermediation and revenue processes, respectively. 


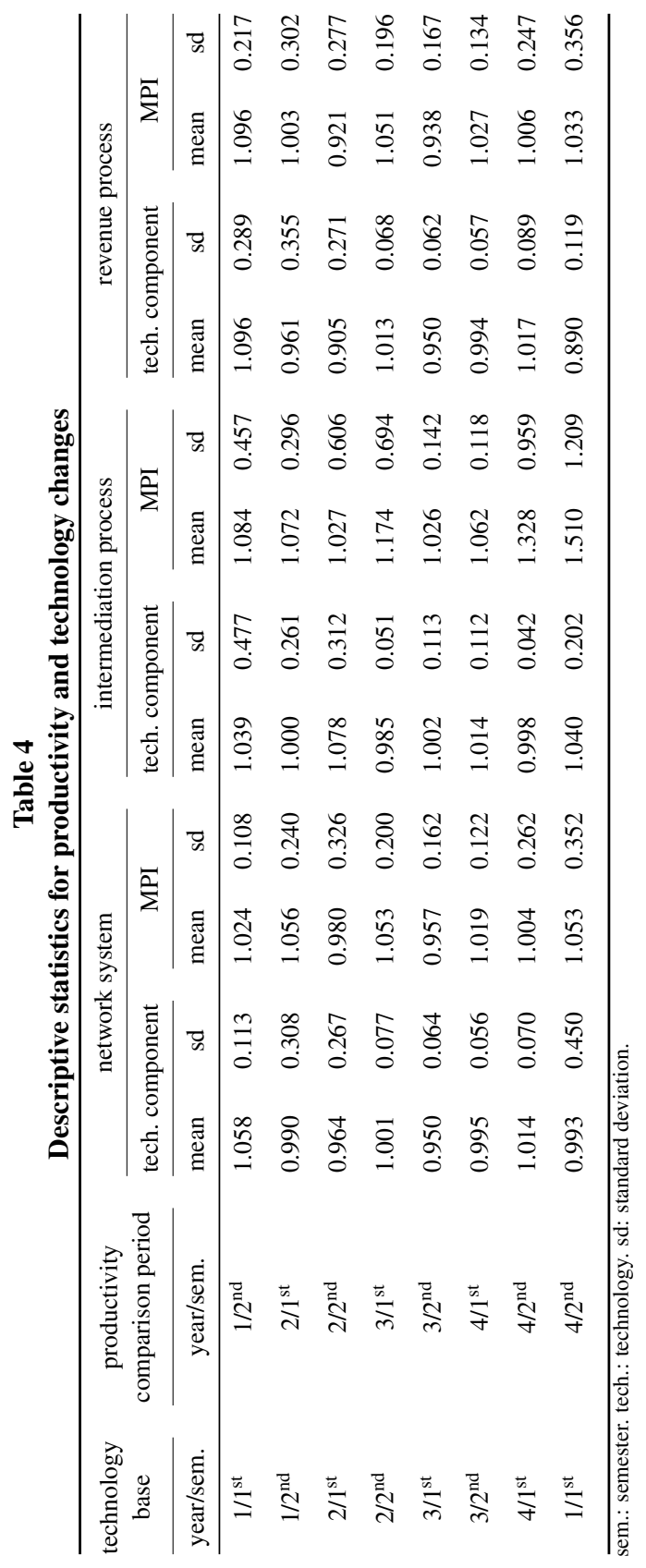


Table 5

Truncated Tobit regression results

\begin{tabular}{|c|c|c|c|c|c|c|}
\hline \multirow[b]{2}{*}{ covariates } & \multicolumn{2}{|c|}{ network system } & \multicolumn{2}{|c|}{ intermediation process } & \multicolumn{2}{|c|}{ revenue process } \\
\hline & coef. & $p$-value & coef. & $p$-value & coef. & $p$-value \\
\hline public & 0.912 & $<0.001 * * *$ & 0.697 & $<0.001 * * *$ & 0.910 & $<0.001 * * *$ \\
\hline domestic & 0.830 & $<0.001^{* * *}$ & 0.915 & $<0.001 * * *$ & 0.805 & $<0.001 * * *$ \\
\hline foreign & 0.924 & $<0.001 * * *$ & 0.910 & $<0.001 * * *$ & 0.899 & $<0.001 * * *$ \\
\hline large & -0.162 & $<0.001 * * *$ & -0.201 & $0.042 * *$ & -0.137 & $0.003 * * *$ \\
\hline holding & -0.106 & $0.021 * *$ & -0.290 & $0.003 * * *$ & -0.127 & $0.005 * * *$ \\
\hline
\end{tabular}

coef.: coefficients. $* ; * ; * * *$ : Statistical significance at $10 \%, 5 \%$, and $1 \%$, respectively.

Regarding changes in the technology component and productivity index between semesters of the same year, no pattern was identified over the four years. This result suggests that the banking cycle has little influence on the performance of banks operating in Brazil.

\subsection{Truncated Tobit regression results}

The estimated coefficients of contextual financial variables for the network system and for intermediation and revenue processes are shown in Table 5. Based on truncated Tobit regression results, we observe that most of the efficiency of banks in the Brazilian credit market can be explained by management strategies related to bank ownership. Foreign banks showed the best performance, followed by public banks and, finally, by domestic banks, when looking from the perspective of the network system, as can be attested by the marginal contributions of $0.9239,0.9124$ and 0.8298 by the corresponding proxies. This fact is related to the balance between the efficiency of intermediation and revenue processes shown by foreign banks, and not observed in other banks due to a high level of inefficiency, 0.6972 and 0.8046 , of intermediation process of public banks and revenue process of domestic banks, respectively.

Table 5 also shows that the coefficients of proxies' largest banks and financial holding companies were significantly negative for network system efficiency, -0.1617 and -0.1062 , respectively. We see a similar negative effect in banking processes. Thus, if the bank is large, and if it belongs to a financial holding company, its efficiency is impaired.

\section{Conclusions}

This study measured and evaluated the comprehensive framework of Brazilian banking industry performance over four years, bringing contributions to literature in different addressed perspectives. 
From a methodological perspective, we can emphasize the application of an analysis that integrates two fundamental dimensions: financial intermediation activities, which are relevant to the economic growth of countries, and the operational activities responsible for profitability, which are relevant to banks' solvency, using a DEA-GMSS model. Among the studies reviewed, we find none with this elaboration for the financial sector in Brazil. In addition, we highlight the structuring of a temporal analysis of changes in productivity and technology in the Brazilian financial sector, based on the integration of the MPI and the DEA-GMSS models.

Our main results point to a tendency towards greater efficiency in the revenue process, in relation to the intermediation process. We can explain this, in part, by the high bank spreads still practiced in the country. These lead, on the one hand, to low levels of improvement of financial technologies and, on the other hand, to a significant increase in the productivity of banks in granting credit.

In practice, the combination of an increase in the supply of credit not accompanied by an improvement of financial technologies can lead to deteriorating controls over credit portfolios. We can also conclude that banks that operate in the Brazilian credit market may incur difficulties in long-term solvency, especially for domestic banks, as their spreads are relatively higher. Additionally, we find that the Brazilian credit market operates under high levels of diseconomies of scale and diseconomies of scope. These diseconomies can be indicated by an intense negative impact on the efficiency of large banks and financial holding companies, in both the network of systems and in the internal processes.

In general, we consider that the abrupt restructuring of Brazil's financial sector was unable to entirely correct its structural problems. Having used mergers and acquisitions as a mechanism of privatization and liberalization of the economy, the restructuring generated a non-competitive environment among banks. This circumstance, in turn, delayed the development of the Brazilian credit market, leading to the prospect of future financial instability.

\section{Acknowledgements}

The authors would like to thank FAPEMIG, CNPq and CAPES for financial support and research incentive.

\section{Compliance with ethical standards}

a Funding. The authors declare no conflict of interest;

b Ethical approval. Not applicable; 
c Informed consent. Not applicable.

\section{References}

Almeida, D. B. d. C. and Jayme Jr., F. G. (2008). Bank consolidation and credit concentration in Brazil (1995-2004), Cepal Review 95: 155-172.

URL: https : / /www . cepal .org/en/publications/11315bank-consolidation-and-credit-concentration-braz il-1995-2004

Avkiran, N. K. (2009). Opening the black box of efficiency analysis: An illustration with UAE banks, Omega 37(4): 930-941.

URL: https://doi.org/10.1016/j.omega.2008.08.001

Avkiran, N. K. (2011). Association of DEA super-efficiency estimates with financial ratios: Investigating the case for Chinese banks, Omega 39(3): 323-334.

URL: https://doi.org/10.1016/j.omega.2010.08.001

Banker, R. D., Cooper, W. W., Seiford, L. M. and Zhu, J. (2011). Returns to scale in DEA, in W. W. Cooper, L. M. Seiford and J. Zhu (eds), Handbook on Data Envelopment Analysis, Springer US, Boston, MA, pp. 41-70.

URL: https : //doi .org/10.1007/978-1-4419-6151-8_2

Banker, R. D. and Natarajan, R. (2008). Evaluating contextual variables affecting productivity using data envelopment analysis, Operations Research 56(1): 48-58.

URL: https: //doi.org/10.1287/opre.1070.0460

Barros, C. P., Tsionas, M. G., Wanke, P. and Azad, M. A. K. (2018). Efficiency in banking of developing countries with the same cultural background, Journal of Economic Studies 45(3): 638-659.

URL: https: //doi .org/10.1108/JES-04-2017-0107

Barros, C. P. and Wanke, P. (2014). Banking efficiency in Brazil, Journal of International Financial Markets, Institutions and Money 28: 54-65.

URL: https://doi.org/10.1016/j.intfin.2013.10.004

Beck, T., Crivelli, J. M. and Summerhill, W. (2005). State bank transformation in Brazil - choices and consequences, Journal of Banking \& Finance 29(8): 2223-2257.

URL: https://doi.org/10.1016/j.jbankfin.2005.03.0 14 
Belaisch, A. (2003). Do Brazilian banks compete?, IMF Working Papers 2003(113).

URL: https://doi.org/10.5089/9781451853728.001

Berg, S. A., Førsund, F. R., Hjalmarsson, L. and Suominen, M. (1993). Banking efficiency in the nordic countries, Journal of Banking \& Finance 17(2): 371-388. Special issue on the efficiency of financial institutions.

URL: https: //doi .org/10.1016/0378-4266 (93) 90038-F

Berg, S. A., Førsund, F. R. and Jansen, E. S. (1992). Malmquist indices of productivity growth during the deregulation of Norwegian banking, 198089, The Scandinavian Journal of Economics 94: S211-S228.

URL: https://doi .org/10.2307/3440261

Berger, A. N. and Humphrey, D. B. (1997). Efficiency of financial institutions: International survey and directions for future research, European Journal of Operational Research 98(2): 175-212.

URL: https://doi.org/10.1016/s0377-2217(96)00342 $-6$

Boháček, R. (2007). Financial intermediation with credit constrained agents, Journal of Macroeconomics 29(4): 741-759.

URL: https://doi.org/10.1016/j.jmacro.2006.03.003

Caves, D. W., Christensen, L. R. and Diewert, W. E. (1982). The economic theory of index numbers and the measurement of input, output, and productivity, Econometrica 50(6): 1393-1414.

URL: https://doi .org/10.2307/1913388

Çelen, A. (2013). Efficiency and productivity (TFP) of the Turkish electricity distribution companies: An application of two-stage (DEA\&Tobit) analysis, Energy Policy 63: 300-310.

URL: https://doi.org/10.1016/j.enpol.2013.09.034

Charnes, A., Cooper, W. and Rhodes, E. (1978). Measuring the efficiency of decision making units, European Journal of Operational Research 2(6): 429-444.

URL: https: //doi.org/10.1016/0377-2217 (78) 90138-8

Chen, Y., Cook, W. D., Li, N. and Zhu, J. (2009). Additive efficiency decomposition in two-stage DEA, European Journal of Operational Research 196(3): 1170-1176.

URL: https://doi.org/10.1016/j.ejor.2008.05.011 
da Silva Fernandes, F., Stasinakis, C. and Bardarova, V. (2018). Two-stage DEA-truncated regression: Application in banking efficiency and financial development, Expert Systems with Applications 96: 284-301.

URL: https : //doi.org/10.1016/j.eswa.2017.12.010

Ebrahimnejad, A., Tavana, M., Lotfi, F. H., Shahverdi, R. and Yousefpour, M. (2014). A three-stage Data Envelopment Analysis model with application to banking industry, Measurement 49: 308-319.

URL: https://doi.org/10.1016/j.measurement.2013.1 1.043

Eggoh, J. C. and Villieu, P. (2014). A simple endogenous growth model of financial intermediation with multiplicity and indeterminacy, Economic Modelling 38: 357-366.

URL: https://doi.org/10.1016/j.econmod.2014.01.017

Färe, R. (1991). Measuring Farrell efficiency for a firm with intermediate inputs, Academia Economic Papers 19(2): 329-340.

Färe, R. and Grosskopf, S. (1996). Productivity and intermediate products: A frontier approach, Economics Letters 50(1): 65-70.

URL: https: //doi .org/10.1016/0165-1765 (95)00729-6

Färe, R., Grosskopf, S., Norris, M. and Zhang, Z. (1994). Productivity growth, technical progress, and efficiency change in industrialized countries, American Economic Review 84(1): 66-83.

URL: http: //www.jstor.org/stable/2117971

Färe, R. and Whittaker, G. (1995). An intermediate input model of dairy production using complex survey data, Journal of Agricultural Economics 46(2): 201-213.

URL: https://doi.org/10.1111/j.1477-9552.1995.tb0 $0766 . x$

Faria Júnior, J. A. d., Paula, L. F. d. and Marinho, A. (2006). Fusões e aquisições bancárias no Brasil: Uma avaliação da eficiência técnica e de escala, Texto para discussão 1233, IPEA.

URL: http: //repositorio.ipea.gov.br/handle/11058/1 733

Farrell, M. J. (1957). The measurement of productive efficiency, Journal of the Royal Statistical Society: Series A (General) 120(3): 253-281. 
Franco, G. H. B. (2000). The Real plan and the exchange rate, Essays In International Finance 217: 1-96.

URL: https: //ies.princeton.edu/pdf/E217.pdf

Freitas, G. A. d., Silva, E. M., Oliveira, M. C., Cabral, A. C. d. A. and Santos, S. M. d. (2018). corporate governance and performance of banks listed in B3 in an economic crisis environment, Journal of Accounting, Management and Governance 21(1): 100-119.

URL: https: / /www.revistacgg.org/contabil/article/ view/1410

Fukuyama, H. and Mirdehghan, S. (2012). Identifying the efficiency status in network DEA, European Journal of Operational Research 220(1): 85-92. URL: https: //doi.org/10.1016/j.ejor.2012.01.024

Greene, W. H. (2018). Econometric Analysis, 8th edn, Pearson Education, New York.

Guo, C., Wei, F., Ding, T., Zhang, L. and Liang, L. (2017). Multistage network DEA: Decomposition and aggregation weights of component performance, Computers \& Industrial Engineering 113: 64-74.

URL: https://doi.org/10.1016/j.cie.2017.08.019

Hoff, A. (2007). Second stage DEA: Comparison of approaches for modelling the DEA score, European Journal of Operational Research 181(1): 425435.

URL: https://doi.org/10.1016/j.ejor.2006.05.019

Johnson, A. L. and Kuosmanen, T. (2012). One-stage and two-stage DEA estimation of the effects of contextual variables, European Journal of Operational Research 220(2): 559-570.

URL: https://doi.org/10.1016/j.ejor.2012.01.023

Kao, C. (2009a). Efficiency decomposition in network data envelopment analysis: A relational model, European Journal of Operational Research 192(3): 949-962.

URL: https://doi.org/10.1016/j.ejor.2007.10.008

Kao, C. (2009b). Efficiency measurement for parallel production systems, European Journal of Operational Research 196(3): 1107-1112.

URL: https://doi.org/10.1016/j.ejor.2008.04.020 
Kao, C. (2014). Efficiency decomposition for general multi-stage systems in data envelopment analysis, European Journal of Operational Research 232(1): 117-124.

URL: https://doi.org/10.1016/j.ejor.2013.07.012

Kao, C. (2017). Measurement and decomposition of the Malmquist productivity index for parallel production systems, Omega 67: 54-59.

URL: https://doi.org/10.1016/j.omega.2016.04.001

Kao, C. and Hwang, S.-N. (2008). Efficiency decomposition in two-stage data envelopment analysis: An application to non-life insurance companies in Taiwan, European Journal of Operational Research 185(1): 418-429.

URL: https://doi.org/10.1016/j.ejor.2006.11.041

Kao, C. and Liu, S.-T. (2014). Multi-period efficiency measurement in data envelopment analysis: The case of Taiwanese commercial banks, Omega 47: 90-98.

URL: https://doi.org/10.1016/j.omega.2013.09.001

Lampe, H. W. and Hilgers, D. (2015). Trajectories of efficiency measurement: A bibliometric analysis of DEA and SFA, European Journal of Operational Research 240(1): 1-21.

URL: https://doi.org/10.1016/j.ejor.2014.04.041

Levine, R., Loayza, N. and Beck, T. (2000). Financial intermediation and growth: Causality and causes, Journal of Monetary Economics 46(1): 3177.

URL: https: //doi.org/10.1016/s0304-3932(00)00017 $-9$

Li, H., Chen, C., Cook, W. D., Zhang, J. and Zhu, J. (2018). Two-stage network DEA: Who is the leader?, Omega 74: 15-19.

URL: https://doi.org/10.1016/j.omega.2016.12.009

liang Yang, G., Fukuyama, H. and yao Song, Y. (2018). Measuring the inefficiency of Chinese research universities based on a two-stage network DEA model, Journal of Informetrics 12(1): 10-30.

URL: https://doi.org/10.1016/j.joi.2017.11.002

Liu, J. S., Lu, L. Y., Lu, W.-M. and Lin, B. J. (2013a). Data envelopment analysis 1978-2010: A citation-based literature survey, Omega 41(1): 3 15. Data Envelopment Analysis: The Research Frontier - This Special Issue is dedicated to the memory of William W. Cooper 1914-2012.

URL: https://doi.org/10.1016/j.omega.2010.12.006 
Liu, J. S., Lu, L. Y., Lu, W.-M. and Lin, B. J. (2013b). A survey of DEA applications, Omega 41(5): 893-902.

URL: https : / /doi.org/10.1016/j.omega.2012.11.004

Luo, X. (2003). Evaluating the profitability and marketability efficiency of large banks: An application of data envelopment analysis, Journal of Business Research 56(8): 627-635.

URL: https://doi.org/10.1016/s0148-2963(01)00293 $-4$

Malmquist, S. (1953). Index numbers and indifference surfaces, Trabajos de Estadistica 4(2): 209-242.

URL: https://doi.org/10.1007/BF03006863

Mariz, F. B., Almeida, M. R. and Aloise, D. (2018). A review of dynamic data envelopment analysis: State of the art and applications, International Transactions in Operational Research 25(2): 469-505.

URL: https://doi .org/10.1111/itor.12468

McCaig, B. and Stengos, T. (2005). Financial intermediation and growth: Some robustness results, Economics Letters 88(3): 306-312.

URL: https://doi.org/10.1016/j.econlet.2004.12.031

Nakane, M. I. and Weintraub, D. B. (2005). Bank privatization and productivity: Evidence for Brazil, Journal of Banking \& Finance 29(8): 2259-2289. URL: https : / doi .org/10.1016/j.jbankfin.2005.03.0 15

Ness, W. L. (2000). Reducing government bank presence in the Brazilian financial system why and how, Quarterly Review of Economics and Finance 40(1): 71-84.

URL: https: //doi.org/10.1016/S1062-9769(99)00045 $-9$

Olivero, M. P., Li, Y. and Jeon, B. N. (2011). Consolidation in banking and the lending channel of monetary transmission: Evidence from Asia and Latin America, Journal of International Money and Finance 30(6): 10341054.

URL: https://doi.org/10.1016/j.jimonfin.2011.06.0 06

Paradi, J. C. and Zhu, H. (2013). A survey on bank branch efficiency and performance research with data envelopment analysis, Omega 41(1): 6179. Data Envelopment Analysis: The Research Frontier - This Special 
Issue is dedicated to the memory of William W. Cooper 1914-2012.

URL: https://doi.org/10.1016/j.omega.2011.08.010

Pastor, J. T., Asmild, M. and Lovell, C. K. (2011). The biennial Malmquist productivity change index, Socio-Economic Planning Sciences 45(1): 1015.

URL: https: //doi.org/10.1016/j.seps.2010.09.001

Portela, M. C. and Thanassoulis, E. (2010). Malmquist-type indices in the presence of negative data: An application to bank branches, Journal of Banking \& Finance 34(7): 1472-1483. Performance Measurement in the Financial Services Sector.

URL: https: //doi .org/10.1016/j.jbankfin.2010.01.0 04

Rho, S. and An, J. (2007). Evaluating the efficiency of a two-stage production process using data envelopment analysis, International Transactions in Operational Research 14(5): 395-410.

URL: https://doi.org/10.1111/j.1475-3995.2007.005 $97 . x$

Seiford, L. M. and Zhu, J. (1999). Profitability and marketability of the top 55 U.S. commercial banks, Management Science 45(9): 1270-1288.

URL: https: //doi .org/10.1287/mnsc .45.9.1270

Shyu, J., Lieu, P.-T. and Chang, W. (2015). How the environment determines banking efficiency: A comparison of banking firms in Taiwan, Hong Kong, and mainland China, International Transactions in Operational Research 22(4): 757-770.

URL: https://doi.org/10.111/itor.12097

Simar, L. and Wilson, P. W. (2007). Estimation and inference in two-stage, semi-parametric models of production processes, Journal of Econometrics 136(1): 31-64.

URL: https://doi.org/10.1016/j.jeconom.2005.07.009

Siriopoulos, C. and Tziogkidis, P. (2010). How do Greek banking institutions react after significant events?-A DEA approach, Omega 38(5): 294-308. Empirical Research in the EU Banking Sector and the Financial Crisis. URL: https://doi.org/10.1016/j.omega.2009.06.001

Staub, R. B., da Silva e Souza, G. and Tabak, B. M. (2010). Evolution of bank efficiency in Brazil: A DEA approach, European Journal of Operational 
Research 202(1): 204-213.

URL: https://doi.org/10.1016/j.ejor.2009.04.025

Sturm, J.-E. and Williams, B. (2010). What determines differences in foreign bank efficiency? Australian evidence, Journal of International Financial Markets, Institutions and Money 20(3): 284-309.

URL: https://doi.org/10.1016/j.intfin.2010.03.008

Tecles, P. L. and Tabak, B. M. (2010). Determinants of bank efficiency: The case of Brazil, European Journal of Operational Research 207(3): 15871598.

URL: https://doi.org/10.1016/j.ejor.2010.06.007

Tone, K. and Tsutsui, M. (2009). Network DEA: A slacks-based measure approach, European Journal of Operational Research 197(1): 243-252. URL: https://doi.org/10.1016/j.ejor.2008.05.027

Turner, H., Windle, R. and Dresner, M. (2004). North American containerport productivity: 1984-1997, Transportation Research Part E: Logistics and Transportation Review 40(4): 339-356. Shipping Finance and Port Issues. URL: https://doi.org/10.1016/j.tre.2003.06.001

Wanke, P., Azad, A. K. and Emrouznejad, A. (2018). Efficiency in BRICS banking under data vagueness: A two-stage fuzzy approach, Global Finance Journal 35: 58-71.

URL: https://doi.org/10.1016/j.gfj.2017.05.001

Wanke, P. and Barros, C. (2014). Two-stage DEA: An application to major Brazilian banks, Expert Systems with Applications 41(5): 2337-2344.

URL: https : / /doi.org/10.1016/j.eswa.2013.09.031

Wanke, P., Barros, C. P. and Faria, J. R. (2015). Financial distress drivers in Brazilian banks: A dynamic slacks approach, European Journal of Operational Research 240(1): 258-268.

URL: https://doi.org/10.1016/j.ejor.2014.06.044

Wanke, P., Maredza, A. and Gupta, R. (2017). Merger and acquisitions in South African banking: A network DEA model, Research in International Business and Finance 41: 362-376.

URL: https://doi.org/10.1016/j.ribaf.2017.04.055

Wijesiri, M. and Meoli, M. (2015). Productivity change of microfinance institutions in Kenya: A bootstrap Malmquist approach, Journal of Retailing 
and Consumer Services 25: 115-121.

URL: https://doi.org/10.1016/j.jretconser.2015.04 .004

Yildirim, H. S. and Philippatos, G. C. (2007). Restructuring, consolidation and competition in Latin American banking markets, Journal of Banking \& Finance 31(3): 629-639.

URL: https://doi.org/10.1016/j.jbankfin.2006.06.0 08

Yu, M.-M. and Lin, E. T. (2008). Efficiency and effectiveness in railway performance using a multi-activity network DEA model, Omega 36(6): 10051017. A Special Issue Dedicated to the 2008 Beijing Olympic Games.

URL: https://doi.org/10.1016/j.omega.2007.06.003

Yuengert, A. M. (1993). The measurement of efficiency in life insurance: Estimates of a mixed normal-gamma error model, Journal of Banking \& Finance 17(2): 483-496. Special Issue on The Efficiency of Financial Institutions.

URL: https: //doi.org/10.1016/0378-4266(93) 90047-H 